\title{
Viral activity in relation to Emiliania huxleyi blooms: a mechanism of DMSP release?
}

\author{
Gunnar Bratbak ${ }^{1, *}$, Maurice Levasseur ${ }^{2}$, Sonia Michaud ${ }^{2}$, Guy Cantin ${ }^{2}$, \\ Emilio Fernández ${ }^{3}$, Berit R. Heimdal ${ }^{4}$, Mikal Heldal ${ }^{1}$ \\ ${ }^{1}$ Department of Microbiology, University of Bergen, Jahnebakken 5, N-5020 Bergen, Norway \\ ${ }^{2}$ Department of Fisheries and Oceans, Maurice Lamontagne Institute, PO BOX 1000, Mont-Joli, Quebec, Canada G5H $3 Z 4$ \\ ${ }^{3}$ Departamento Recursos Naturais e Medio Ambiente, Facultad de Ciencias del Mar, Campus Lagoas-Marcosende, \\ Universidade de Vigo, E-36200 Vigo, Spain
}

${ }^{4}$ Department of Fisheries and Marine Biology, University of Bergen, Bergen High Technology Centre, N-5020 Bergen, Norway

\begin{abstract}
The role of viral activity with respect to bloom dynamics and production of dissolved dimethylsulfoniopropionate (DMSP) and dimethylsulfide (DMS) was investigated in Norwegian coastal waters and in sea water mesocosms during blooms of the coccolithophorid Emiliania huxleyi (Lohm.) Hay \& Mohler. In coastal waters the collapse of the E. huxleyi bloom was accompanied by a simultaneous increase in large virus-like particles (LVLP) and there was a significant inverse relationship between cell-specific calcification rate and LVLP abundance. Results from the mesocosm study indicate that the viral activity may either prevent or terminate the development of E. huxleyi blooms. No significant relationships were found between the abundance of LVLPS and the concentrations of dissolved DMSP and DMS in the field or in the mesocosms. This may be explained by the relatively small size of the E. huxleyi blooms (maximum cell concentration of $11 \times 10^{6} 1^{-1}$ ) and bacterial degradation of DMSP and DMS, which may have been sufficient to prevent the accumulation of sulfur compounds released after lysis of the cells.
\end{abstract}

KEY WORDS: Phytoplankton - Emiliania huxleyi Virus-like particles · VLP - Dimethylsulfoniopropionate $\cdot$ Dimethylsulfide $\cdot$ Calcification $\cdot$ Mesocosm

\section{INTRODUCTION}

The ecological significance of the marine coccolithophorid Emiliania huxleyi (Lohm.) Hay \& Mohler is based on its worldwide distribution and its formation of massive blooms in both oceanic and coastal waters (Holligan et al. 1983, Balch et al. 1992). This alga is considered to be among the largest producers of calcite on earth and a major vehicle for the transport of carbon to the deep sediments (Dymond \& Lyle 1985, Westbroek et al. 1985, Westbroek 1991). In addition, E. huxleyi is an important producer of dimethylsulfide (DMS), a gas thought to play a significant role in climate regulation (see review by Malin et al. 1992).

•E-mail: gunnar.bratbak@im.uib.no
Viruses and virus-like particles (VLPs) have been found in algae from all major taxonomic classes, but reports on free algal viruses in natural environments are rare. In 2 recent reports (Suttle et al. 1990, 1991) it was concluded that viruses concentrated from natural sea water may infect a variety of important marine primary producers, including diatoms and prasinophytes. The ecological roles of algal viruses in natural ecosystems are, however, largely unknown. As far as microalgae are concerned, the only host - virus systems that have been investigated to any extent are Chlorella sp. (strain NC64A) (van Etten et al. 1991, Reisser 1993) and Micromonas pusilla (Mayer \& Taylor 1979, Waters $\&$ Chan 1982, Cottrell \& Suttle 1991) and their viruses Virus of Emiliania huxleyi has been reported to terminate blooms of this species in mesocosm experiments (Bratbak et al. 1993). The viruses acted in this case as a 
population controlling factor and they affected community composition by decimating one specific population and making blooms of succeeding populations possible. The viral activity appeared to be related to the nutrient status of the host cells, as the virus production was most significant when orthophosphate was in surplus. Decrease in E. huxleyi population density in natural waters has also been related to concomitant increases in viral abundance (Bratbak et al. 1993).

DMS is the most abundant volatile sulfur compound in sea water (Malin et al. 1993 and references therein). It oxidizes to $\mathrm{SO}_{2}$ and sulfuric acid when it enters the atmosphere and it is a significant source of natural acid rain. DMS may also have implications for global climate, as it enhances cloud formation by forming aerosols and serving as cloud condensation nuclei (Charlson et al. 1987). DMS is a decomposition product of dimethylsulfoniopropionate (DMSP) which is produced by certain phytoplankton groups in which it is presumed to play a role in osmoregulation (Vairavamurthy et al. 1985, Dickson \& Kirst 1987 a, b). Significant production of DMSP is confined to a few algal classes, primarily the Dinophyceae and the Prymnesiophyceae, which includes the coccolithophorids (Keller 1989). Emilania huxleyi is among the few algae that in the field have been recognized as a significant source of DMS (Turner et al. 1988, Malin et al. 1993, Matrai \& Keller 1993). DMSP release from cells is low during active growth but increases during declining or stationary growth phases, probably as a result of cell autolysis or osmotic changes in the cell (Nguyen et al. 1988, Turner et al. 1988). Zooplankton grazing on DMSP-producing phytoplankton has also been shown to increase DMS production significantly but the mechanism is unclear (Dacey \& Wakeham 1986). Although never reported, cell autolysis following viral infection may also represent an important mechanism of DMSP release in nature (Malin et al. 1992).

The objectives of this study were to investigate in the field and in mesocosms: (1) the role of viruses as a population controlling factor for Emiliania huxleyi, (2) the relationship between viral activity and physiological state of the E. huxleyi population as indicated by cellspecific calcification rate, and (3) the potential importance of viral activity as a mechanism of DMS production in nature.

\section{MATERIALS AND METHODS}

Field sampling and experimental setup. Field study: The field study was carried out in Fauskangerpollen on the west coast of Norway about $20 \mathrm{~km}$ northwest of Bergen $\left(60^{\circ} 31^{\prime} \mathrm{N}, 5^{\circ} 02^{\prime} \mathrm{E}\right)$. Fauskangerpollen is a $2.5 \mathrm{~km}$ long (north-south) and $750 \mathrm{~m}$ wide (east-west) land-locked fjord with a single $92 \mathrm{~m}$ deep basin. The inlet is $40 \mathrm{~m}$ wide and the depth at the sill is $4 \mathrm{~m}$ (Johannessen \& Heimdal 1979). The freshwater runoff is relatively low due to a small drainage area of only 1.7 times the area of the fjord. The narrow inlet, the deep basin and the small influence of the surrounding land masses on the hydrography make Fauskangerpollen well suited for studying defined water masses. In addition, the water in Fauskangerpollen is known to become greenish-white in May-June every year due to dense Emiliania huxleyi blooms.

We followed the Emiliania huxleyi bloom in Fauskangerpollen as it collapsed at the end of May 1993. Water samples were collected in the middle of the fjord on May 19, 24 and 26, 1993, from RV 'Hans Brattstrøm'. The samples were taken with a Niskin bottle sampler from several depths between 0 and $15 \mathrm{~m}$, preserved or treated according to the individual analysis and brought back to the laboratory.

Mesocosm study: The mesocosm experiments were carried out between May 10 and June 1, 1993, in a bay next to the Marine Biological Field Station (Espeland) adjacent to Raunefjorden, $20 \mathrm{~km}$ south of Bergen, western Norway. The enclosures were mounted on floating frames that were moored on the southern side of a raft in the middle of the bay (for details see Egge \& Aksnes 1992). They were $4 \mathrm{~m}$ deep and $2 \mathrm{~m}$ wide (volume: $11 \mathrm{~m}^{3}$ ), made of $0.15 \mathrm{~mm}$ thick polyethylene (90\% penetration of photosynthetically active radiation, PAR) and open to the air. Homogeneous water masses within the enclosures were ensured by an airlift system that pumped water from the bottom of the enclosures to the surface at a rate of $401 \mathrm{~min}^{-1}$

The mesocosm experiment was started according to the following schedule. May 10: The enclosures were filled with sea water from $1 \mathrm{~m}$ depth. May 11: Two enclosures (L.1 and L2, L for low N:P ratio) were enriched with nutrients $\left(\mathrm{NaNO}_{3}\right.$ and $\left.\mathrm{K}_{2} \mathrm{HPO}_{4}\right)$ to give initial nutrient concentrations of about $10 \mu \mathrm{M}$ nitrate and about $3.5 \mu \mathrm{M}$ orthophosphate. A third enclosure ( $\mathrm{H} 2, \mathrm{H}$ for high N:P ratio) was enriched with nitrate and orthophosphate to give initial nutrient concentrations of about $10 \mu \mathrm{M}$ nitrate and about $0.2 \mu \mathrm{M}$ orthophosphate. From May 13 onwards: The water in the enclosures was renewed continuously at a rate of $10 \% \mathrm{~d}^{-1}$ with water pumped in from $1 \mathrm{~m}$ depth. From May 14 onwards: $10 \%$ of the initial nutrient concentration was added to the enclosures at noon every day, i.e. after the daily sampling, in order to replace the nutrients lost in the outflow. One water sample was collected daily from each of the enclosures by submersing a 101 carboy below the surface. These samples were distributed and used in all subsequent analysis

Sample analysis. Samples for determination of nitrate and phosphate concentrations were analyzed in a 
Skalar autoanalyzer. In the mesocosm experiment the samples were analyzed within $3 \mathrm{~h}$ after sampling while samples from Fauskangerpollen were analyzed within $24 \mathrm{~h}$. Salinity was measured with a salinometer and temperature was measured with a thermometer inside the water sampler. Phytoplankton identification and enumeration were performed by examining samples preserved in both Lugol's iodine and buffered formalin. with an inverted microscope (Utermöhl 1931).

Free VLPs were counted in samples preserved with neutral formaldehyde. The samples were acidified with 2 or 3 drops of $1 \mathrm{~N} \mathrm{HCl}$ to dissolve detached coccoliths of Emiliania huxleyi that otherwise would cover the preparations completely. Suspended particles were harvested by centrifugation $(200000 \times g, 1 \mathrm{~h})$, prepared for transmission electron microscopy (TEM) and counted as described earlier (Børsheim et al. 1990, Bratbak et al. 1990). The VLPs we related to E. huxleyi were recognized by size and morphology (see 'Results') and counted at $20000 \times$ magnification. A total of 10 to 300 VLPs in 25 to 50 fields were counted for each sample, yielding a counting error of between 6 and $32 \%$

Calcification rates were measured by the ${ }^{14} \mathrm{C}$ method (Paasche 1963) as described by Fernández et al. (1993). Water samples were transferred to $70 \mathrm{ml}$ polycarbonate bottles and inoculated with $370 \mathrm{kBq} \mathrm{NaH}{ }^{14} \mathrm{CO}_{3}$. In the mesocosm experiments the samples were incubated in situ, while in the field study we used a watercooled artificial-light incubator that simulated a range of irradiance levels corresponding to the irradiance experienced by the algae at the sampling depths. After a $24 \mathrm{~h}$ incubation period the samples were split into 2 fractions. Both fractions were filtered through $0.2 \mu \mathrm{m}$ Poretics polycarbonate filters and rinsed 3 times with $0.2 \mu \mathrm{m}$ filtered sea water. The filter from one fraction was exposed to concentrated $\mathrm{HCl}$ fumes for 3 to $5 \mathrm{~min}$ and dried in a desiccator. The efficiency of the decontamination procedure was continuously monitored by running parallel incubations with blanks consisting of water samples previously treated with $1 \%$ buffered formalin. Calcification rates were calculated as the difference between the activity measured on the unfumed and fumed filters. Quenching was corrected using the channels ratio method. Cell-specific calcification rates were calculated as calcification per Emiliania huxleyi cell and interpreted as an indicator of physiological state of the coccolithophores (Balch et al. 1992).

For particulate DMSP determination, two $60 \mathrm{ml} s u b-$ samples were filtered on Whatman GF/F filters which were placed in $25 \mathrm{ml}$ vials filled with $24 \mathrm{ml}$ of distilled water and $1 \mathrm{ml}$ of $5 \mathrm{M} \mathrm{KOH}$. For dissolved DMSP + free DMS determination, two $25 \mathrm{ml}$ vials were filled with $24 \mathrm{ml}$ of filtrate and $1 \mathrm{ml}$ of $5 \mathrm{M} \mathrm{KOH}$. For free DMS determination, two $25 \mathrm{ml}$ vials were filled with $24 \mathrm{ml}$ of filtrate and $1 \mathrm{ml}$ of deionized $\mathrm{H}_{2} \mathrm{O}$. All vials were immediately sealed with a Teflon-faced serum cap and held in the dark until analyzed. DMS samples were analyzed less than $2 \mathrm{~h}$ after the sampling while DMSP (as DMS) samples were measured during the following 2 mo. DMS was measured on a Varian 3400 gas chromatograph equipped with a flame photometric detector and a Chromosil 330 Tefion column following a modified version of the method described by Leck \& Bagander (1988). Samples were sparged with $\mathrm{N}_{2}$ gas $\left(30 \mathrm{ml} \mathrm{min}^{-1}\right)$, and cryotrapped in a Teflon loop submerged in liquid nitrogen. The Teflon loop was subsequently heated $\left(\mathrm{ca} 80^{\circ} \mathrm{C}\right.$ ), releasing the collected sample onto the column. Using the specific reaction which cleaves DMSP into equimolar amounts of DMS upon alkali treatment (Challenger \& Simpson 1948), the measured quantity of DMS in filtered samples represented the amounts of dissolved DMSP and free

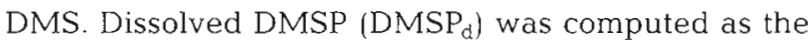
difference between (DMSP + DMS) and DMS. Standards, prepared from known quantities of DMSP, were analyzed in similar fashion. During the cruises, the lag period between the collection of the samples and their analysis in the shore laboratory was too long to obtain reliable DMS measurements. For this reason, only pooled $\mathrm{DMSP}_{\mathrm{d}}+\mathrm{DMS}$ concentrations are available for the cruises.

\section{RESULTS}

\section{Field study}

The hydrographical data (Fig. 1a, b) indicate that there was an inflow of warmer and less saline water above the pycnocline at ca $5 \mathrm{~m}$ depth in Fauskangerpollen between the first 2 sampling dates. The thermohaline properties of the intermediate layer (the layer below the halocline) remained unchanged throughout the study. Nitrate concentrations were always low $(<0.9 \mu \mathrm{M})$, particularly at the pycnocline where they reached undetectable concentrations (Fig. 1c). Phosphate concentrations were relatively constant at ca $0.2 \mu \mathrm{M}$ during the 3 cruises, with no particular vertical pattern (Fig. 1d)

The sampling in Fauskangerpollen started at the peak of the Emiliania huxleyi bloom (E. Fernández et al. unpubl.) (Fig. 2a), Above the pycnocline, the E. huxleyi population was decimated between May 19 and 24, possibly as a result of the advection of the low salinity water mass (Fig. 1b). Below $5 \mathrm{~m}$ depth, the abundance of $E$. huxleyi also decreased, but with no apparent changes in the physical characteristics of the water mass. At all depths (except $15 \mathrm{~m}$ ), the changes observed in the abundance of diatoms (dominated by 


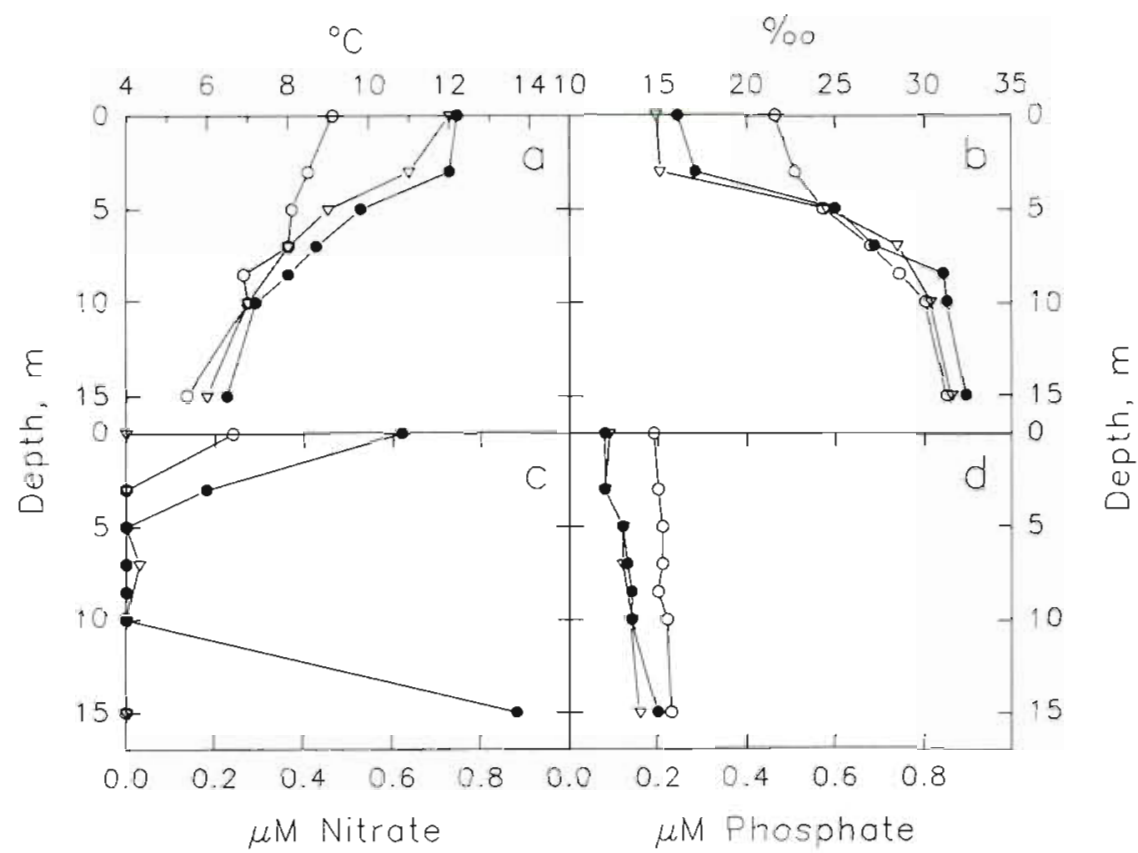

Skeletonema costatum) and flagellates were small compared to the collapse of the E. huxleyi bloom (Fig. 2b, c). The collapse of the E. huxleyi bloom was generally paralleled by an increase in LVLP concentrations (Fig. 2d). Above $10 \mathrm{~m}$ depth, the abundance of LVLP increased between May 19 and 24. It remained constant or started to decrease above $5 \mathrm{~m}$ between May 24 and 26 while it continued to increase below $5 \mathrm{~m}$. The LVLPs, which had a hexagonal outline and were about $140 \mathrm{~nm}$ in diameter (Fig. 3), were smaller than the one previously observed by Bratbak et al. (1993) during $E$. huxleyi blooms (i.e. about $180 \mathrm{~nm}$ ).

The calcification rate was highest at about $5 \mathrm{~m}$ depth on May 19 and tended to decrease as the Emiliania huxleyi bloom collapsed (Fig. 4a). The cell-specific calcification rates exhibited considerable variations between depths and cruises with values ranging from 0.2 to $8.6 \mathrm{pg} \mathrm{C}$ cell $^{-1} \mathrm{~d}^{-1}$ (Fig. 4b). The high calcification rates measured at $5 \mathrm{~m}$ on May 19 and near the surface on May 26 were similar to the maximum calcification rate previously reported for healthy $E$. huxleyi populations ( 6 pg C cell ${ }^{-1} \mathrm{~d}^{-1}$; Balch et al. 1992), suggesting that the E. huxleyi bloom was in a healthy physiological state.

The concentrations of particulate DMSP (DMSP $)$ were positively correlated with the abundance of Emiliania huxleyi in Fauskangerpollen $(\mathrm{r}=0.73, \mathrm{p}<0.001$, $\mathrm{n}=18$ ), suggesting that $E$. huxleyi represented an important source of DMSP during the cruises. As expected, the general decline with time of the E. huxleyi bloom was accompanied by a decrease in $\mathrm{DMSP}_{\mathrm{p}}$ concentrations (Fig. 5a). The collapse of the E. huxleyi
Fig. 2. Vertical distribution of the abundance of (a) Emiliania huxleyi, (b) diatoms, (c) flagellates and (d) large virus-like partıcles (LVLP) in Fauskangerpollen on May 19 (0). May $24(\bullet)$ and May $26(\nabla), 1993$
Fig. 1 Vertical distribution of (a) temperature, (b) salinity, (c) nitrate concentrations and (d) phosphate concentrations in Fauskangerpollen on May 19 (O), May $24(\bullet)$ and May $26(\nabla), 1993$

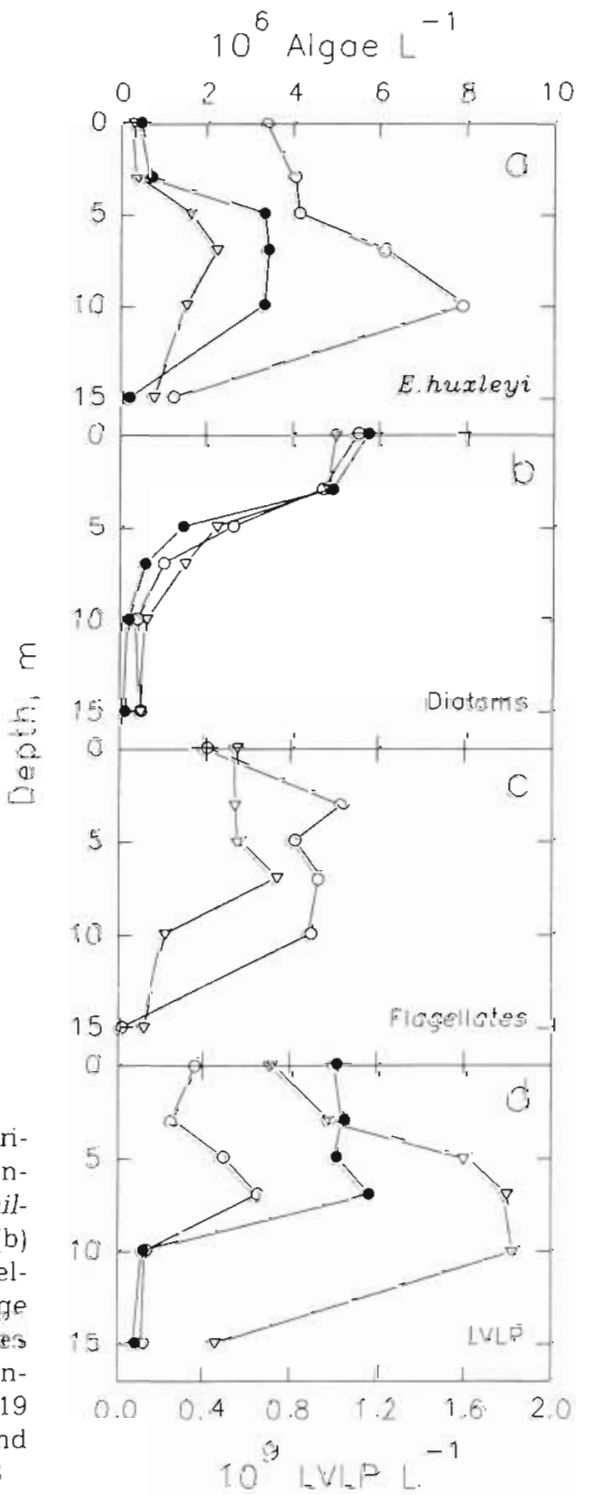




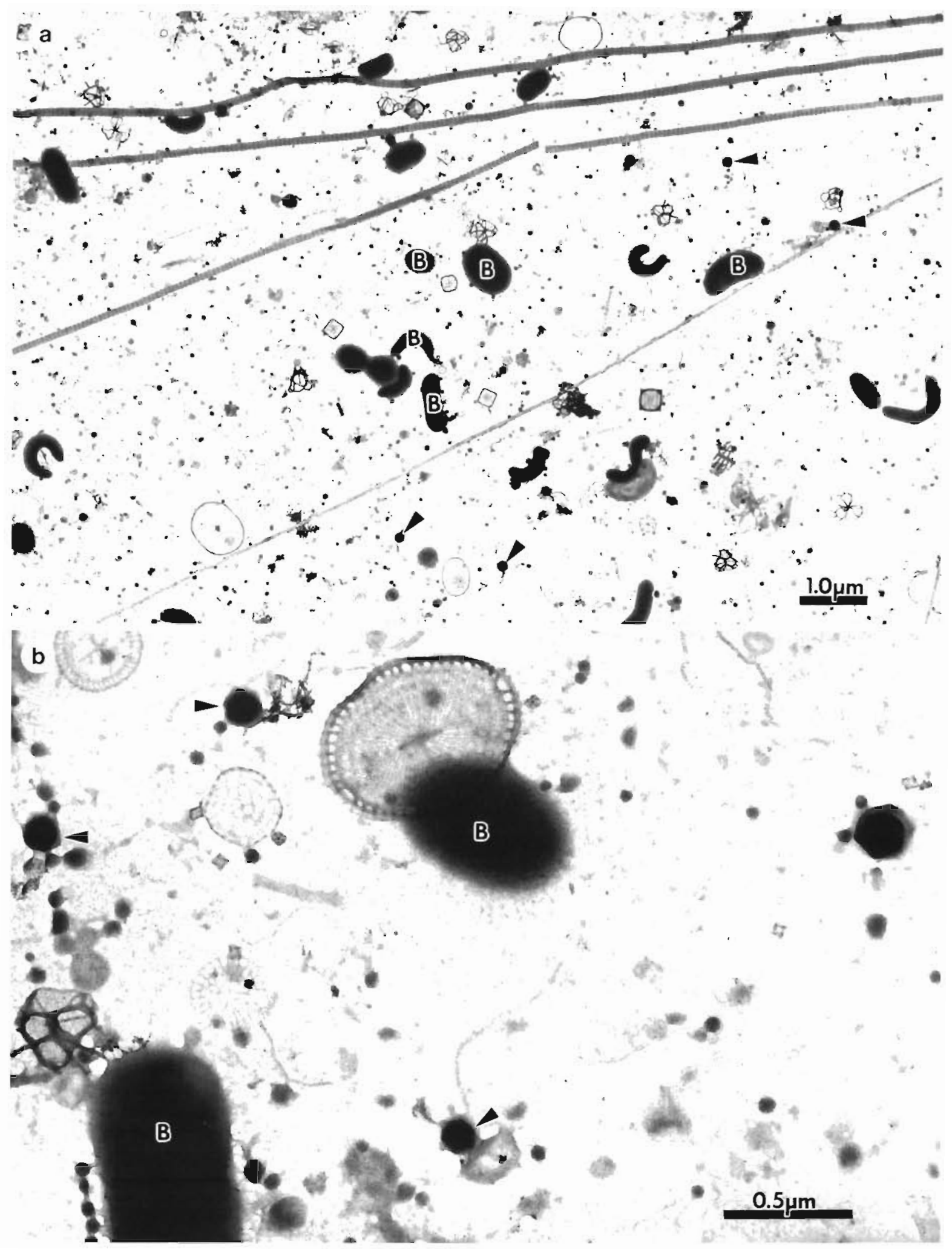

Fig. 3. Electron micrographs of virus-like particles and bacteria in Fauskangerpollen during the collapse of the Emiliania huxleyi bloom. (a) Overview showing the variety of particles collected by centrifugation, including bacteria (B) and the LVLPS (arrowheads) we associated with the E. huxleyi bloom. (b) Close-up showing 3 of the LVLPs (arrowheads), several smaller and one larger VLP, and bacteria (B) 

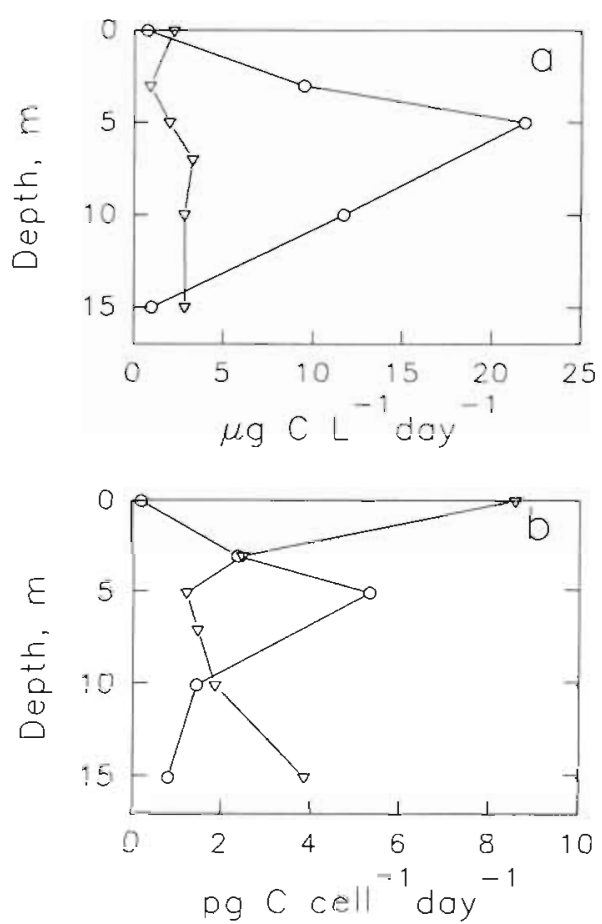

Fig. 4. Vertical variations of (a) calcification rate and (b) cellspecific calcification rate in Fauskangerpollen on May 19 (아 and May $26(\nabla), 1993$
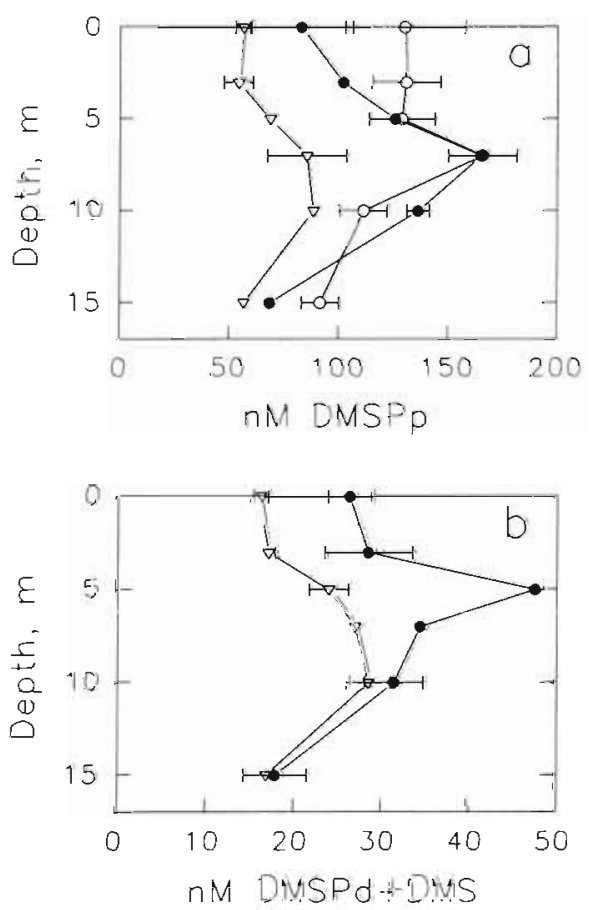

Fig. 5. Vertical distribution of the concentrations of (a) particulate DMSP (DMSP $)$ and (b) dissolved DMSP and dimethylsulfide (DMSP + DMS) in Fauskangerpollen on May 19 (O). May $24(\bullet)$ and May $26(\nabla), 1993$. Data for DMSP + DMS were only available for May 24 and 26 bloom was not, however, accompanied by an increase in DMSP $_{d}+$ DMS concentrations (Fig. 5b). Between May 24 and 26, DMSP + DMS concentrations decreased in the entire water column, following the general decline of the E. huxleyi population. As observed for DMSP $_{p}, \mathrm{DMSP}_{d}+\mathrm{DMS}_{\mathrm{S}}$ concentrations were positively correlated with the abundance of E. huxleyi during the cruises $(\mathrm{r}=0.815, \mathrm{p}<0.001, \mathrm{n}=12$ ). We found no significant positive relationship between the abundance of LVLPs and the concentration of DMSP $_{d}+$ DMS in the water column (Fig. 6a).

\section{Mesocosm experiments}

The phytoplankton succession in L1 was characterized by 2 Emiliania huxleyi blooms of different magnitude (Fig. 7a). E. huxleyi concentrations reached ca $2.3 \times 10^{6}$ cells $1^{-1}$ during the first bloom and

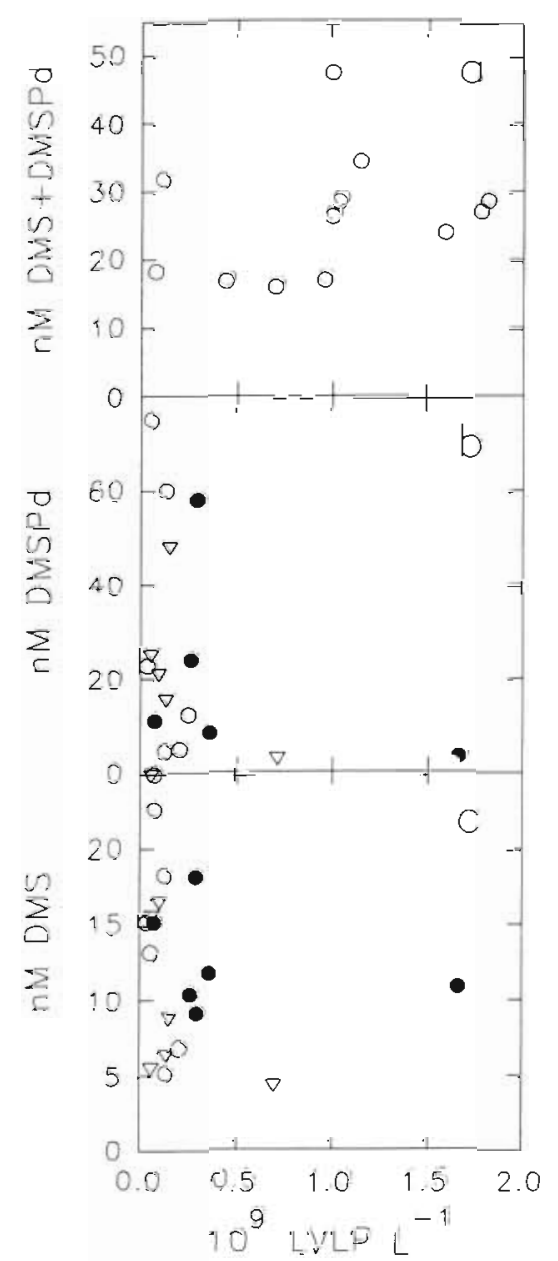

Fig. 6. Relationship between LVLP concentrations and (a) DMSP $_{d}+$ DMS concentrations in Fauskangerpollen, (b) DMSP concentrations in the enclosures and (c) DMS concentrations in the enclosures. (O) $\mathrm{L} 1,(\bullet) \mathrm{L} 2,(\nabla) \mathrm{H} 2$ 


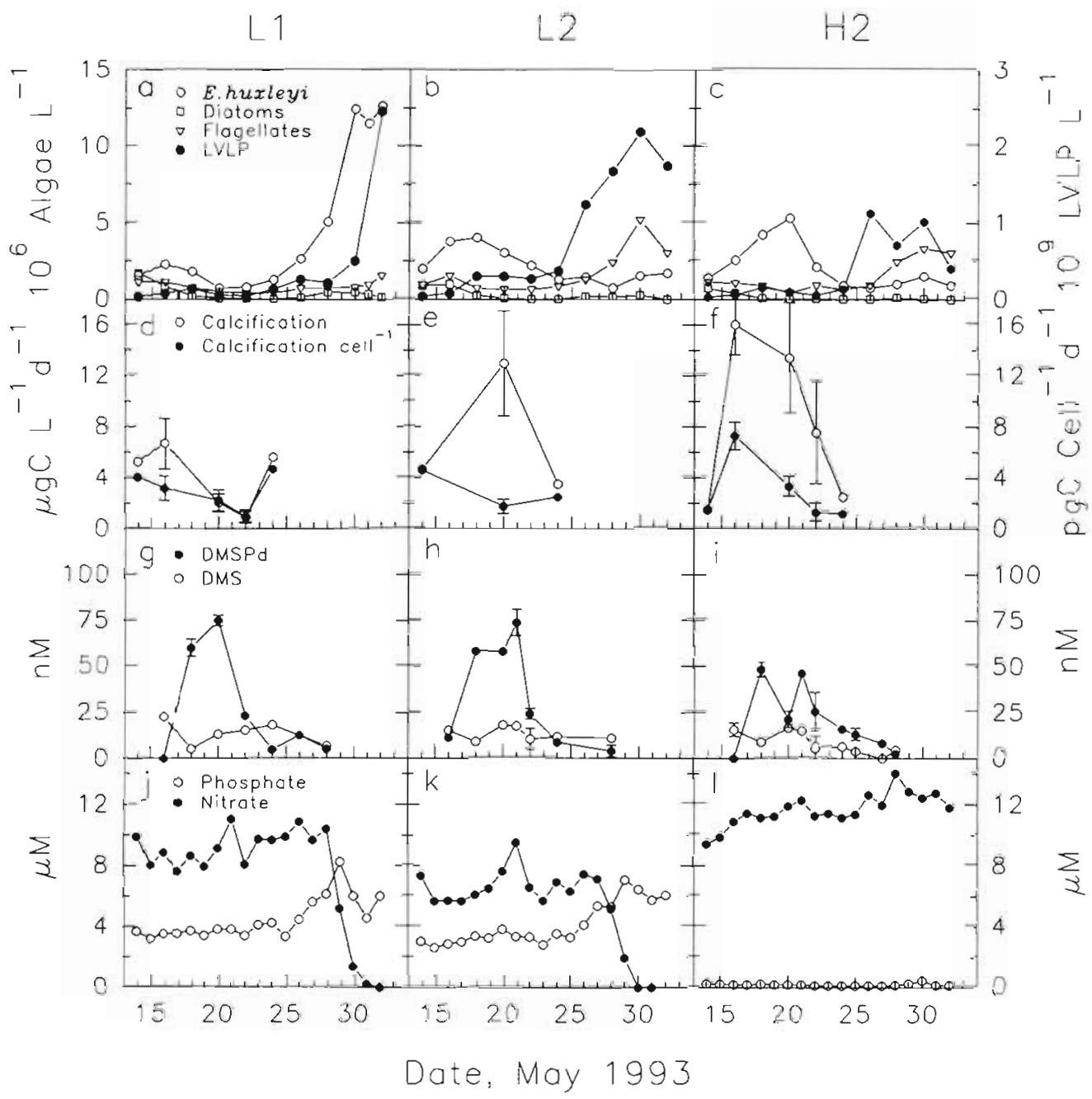

ca $12 \times 10^{6}$ cells $1^{-1}$ during the second one at the end of the experiment. The abundance of Skeletonema costatum, which dominated the diatom community, and of other algae decreased from the start of the experiment and stayed low throughout. As previously observed during similar mesocosm experiments (Bratbak et al. 1993), the first small and second large E. huxleyi blooms were both succeeded by a proportional increase in LVLP abundance (Fig. 7a).

The early Emiliania huxleyi bloom in L2 and $\mathrm{H} 2$

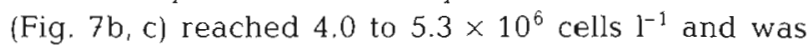
thus more pronounced than the corresponding bloom in L1 (Fig. 7a). A bloom of small flagellates, predominantly cf. Prasinocladus sp. and Syracosphaera sp., occurred at the end of the experiment and replaced the second E. huxleyi bloom in L1 with abundances of 3.3 to $5.2 \times 10^{6}$ cells $^{-1}$ (Fig. $7 \mathrm{~b}, \mathrm{c}$ ). However, the development with respect to other algae in the community was similar to L1. LVLP abundance increased slightly in both enclosures during the E. huxleyi bloom and more drastically 4 to $6 \mathrm{~d}$ following the collapse of the E. hux- leyi bloom. The latter increase in LVLP abundance coincided with the onset of the flagellate bloom in these enclosures. The LVLP population was morphologically homogeneous in all enclosures. The particles had a hexagonal outline and were about $140 \mathrm{~nm}$ in diameter. Their size and morphology were similar to those found in Fauskangerpollen in the field study (Fig. 3),

The calcification rate in the mesocosm experiments (Fig. 7d-f) was correlated with the abundance of Emiliania huxleyi ( $\mathrm{r}=0.803, \mathrm{p}<0.001, \mathrm{n}=13$ ). Excluding the initial low value in $\mathrm{H} 2$ (Fig. $7 \mathrm{f}$ ), the cell-specific calcification rate was related to the growth state of E. huxleyi, decreasing from $7.3-4.1$ to $1-2.5 \mathrm{pg} \mathrm{C}$ cell ${ }^{-1} \mathrm{~d}^{-1}$ throughout the initial bloom in all 3 enclosures (Fig. $7 \mathrm{~d}-\mathrm{f}$ ).

The concentration of dissolved DMSP and DMS peaked as the initial Emiliania huxleyi bloom culminated and declined thereafter (Fig, 7g). As discussed elsewhere (M. Levasseur et al. unpubl.), the increase in DMSP $_{d}$ and DMS is attributed to the lysis of the 
earlier diatom bloom. As observed in the field, the collapse of the first small E. huxleyi bloom was accompanied by a decrease in $\mathrm{DMSP}_{\mathrm{d}}$ and DMS concentrations and we found no positive relationship between the abundance of LVLPS and the concentration of either DMSP or DMS (Fig. 6b, c)

\section{DISCUSSION}

\section{LVLP - host interaction}

Current methods for direct counting of VLPs do not provide information which relates them to any specific host organism. The host-virus relationship must thus be inferred mostly from the morphology of the viruses and the co-distribution of the viruses with their possible hosts. The morphology of the LVLPs was similar in the enclosures and in Fauskangerpollen and, consequently, we assume that they were produced by the same host species. The size of the LVLPs does not rule out bacteria as possible hosts (Fig. 3), but the VLPS observed inside or around bacteria were much smaller (ca 30 to $60 \mathrm{~nm}$ in diameter) than the LVLPs (ca $140 \mathrm{~nm}$ in diameter).

The co-distribution of phytoplankton and LVLP in the enclosures and in Fauskangerpollen suggests that Emiliania huxleyi was the host of the LVLPs. E. huxlevi was the most abundant phytoplankton species in the enclosures when the LVLPs started to increase in abundance. In Fauskangerpollen, E. huxleyi was outnumbered by Skeletonema costatum in the surface waters but dominated below the pycnocline. The low population densities of most other phytoplankton and heterotrophic microzooplankton species makes them unlikely host organisms, unless we assume them to have unreasonably high burst sizes or growth rates. The LVLPs found in the enclosures and in Fauskangerpollen were, however, smaller than the LVLPs reported earlier for $E$. huxleyi (180 to $220 \mathrm{~nm}$ in diameter; Manton \& Leadbeater 1974, Bratbak et al. 1993). This may indicate that there are several different host - virus systems for this alga.

Results from Fauskangerpollen and L1 support our previous observation that viruses may terminate the development of Emiliania huxleyi blooms. In Fauskangerpollen, the changes in IVLP abundance tended to be inversely related to the changes in abundance of E. huxleyi, but it is only between the first and last sampling date and below the surface waters ( 3 to $15 \mathrm{~m}$ ) that we found a significant negative correlation between the 2 parameters ( $r=-0.891, p=0.042, n=5$ ). One possible interpretation of this is that the changes in the abundance of E. huxleyi observed in the surface waters were also influenced by the exchange of water taking place between May 19 and 24, and that the development is not simultaneous in all parts of the water column. In L1, the abundance of the LVLPS increased as the E. huxleyi concentration increased, and the E. huxleyi population seemed to stop growing when the LVLP abundance exceeded $0.5 \times 10^{9} \mathrm{I}^{-1}$. The virus-E. huxleyi co-distribution in Fauskangerpollen and in L1 was thus basically similar to that previously observed during similar enclosure experiments (Bratbak et al 1993), i.e. the abundance of LVLP increases as the growth of the algae ceases, and the bloom terminates and collapses

The development in $\mathrm{L} 2$ and $\mathrm{H} 2$ was different from the development observed in L1 and in Fauskangerpollen, as the increase in LVLP abundance in these enclosures occurred while the host population was relatively low, and moreover was not accompanied by a simultaneous decrease in host abundance. As a tentative hypothesis, we may suggest that the viruses in $\mathrm{L} 2$ accumulated at the expense of the host and thus prevented the Emiliania huxleyi bloom from developing in this enclosure. This is an ecological role of the viruses that we have had no indication of before. In Fauskangerpollen, in L1 and in earlier studies (Bratbak et al. 1993) the viruses have always terminated blooms of E. huxleyi, not prevented it.

The development in L2 and $\mathrm{H} 2$ was similar but the collapse of the Emiliania huxleyi bloom in $\mathrm{H} 2$ was more evident than in L2. The lower LVLP abundance in $\mathrm{H} 2$ as compared to L1 and L2 may be explained by the lower phosphate concentration in this enclosure, as virus production may be restricted by low phosphorus supply (Bratbak et al. 1993)

\section{LVLP and the physiological state of the Emiliania huxleyi population}

Balch et al. (1992) have shown that cell-specific calcification rates decrease or even cease during stationary phases of growth in cultures of Emiliania huxleyi. Studying a large-scale coccolithophorid bloom in the northeast Atlantic, Fernández et al. (1993) found that low biomass-normalized calcification rates were related to low rates of chlorophyll $a$ normalized photosynthesis. These studies support the idea of a close connection between cell-specific calcification rate and growth state and/or physiological state of E. huxleyi. The E. huxleyi population sampled in Fauskangerpollen on May 19 was growing actively, at least at $5 \mathrm{~m}$ depth where the cell-specific calcification rate was about $6 \mathrm{pg} \mathrm{C}$ cell $\mathrm{l}^{-1} \mathrm{~d}^{-1}$, i.e. within the range of maximum calcification rates for this species (Balch et al. 1992). On this date there was a positive correlation between LVLP abundance 
and cell-specific calcification $(\mathrm{r}=0.679, \mathrm{p}=0.011$, $n=13$ ), while $1 \mathrm{wk}$ later on May 26, when the $E$. huxleyi bloom had collapsed, there was a negative correlation ( $r=-0.679, p=0.025, n=10$ ). One interpretation of this is that the physiological state of $E$. huxleyi was not negatively affected by viruses on May 19. On May 26 the physiological state of the E. huxleyi population had deteriorated as a result of viral attack, and accordingly there was a negative correlation between virus and calcification per cell. Thus, in Fauskangerpollen, we found a significant negative relationship between the physiological state of E. huxleyi and the abundance of LVLPS only at the time of bloom termination. However, we did not find any such relationship in the enclosures as, unfortunately, no calcification measurements were carried out from May 25 onwards, when LVLP started to play a significant role in the development of $E$. huxleyi populations.

\section{The elusive virus/DMS connection}

Although never demonstrated yet, cell lysis following viral infection should represent an efficient mechanism of DMSP $P_{d}$ release and DMS production in nature (Malin et al. 1992). Since both LVLPs and DMSP $P_{d}$ are released during cell lysis, one would expect to see their concentration covary. Our results failed to evidence such a relationship.

DMSP quotas are highly species-specific (see 'Introduction') and bacterial degradation represents the

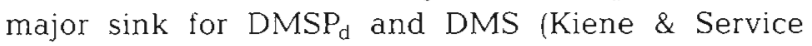
1991). The absence of a relationship between LVLP and DMSP $_{d}$ (and DMS) may thus result either from the small DMSP quota of the infected cells or a rapid rate of bacterial degradation of the released DMSP. Since Emiliania huxleyi, the presumed host of the viruses, is notorious for its high DMSP quota (see 'Introduction') and was partially responsible for the variations in particulate DMSP both in the field and in the enclosures (this study; M. Levasseur et al. unpubl.), we must reject the first explanation.

Kiene (1990) found that there is a significant potential for microbial conversion of $\mathrm{DMSP}_{d}$ to DMS in coastal sea water. The concentration of $\mathrm{DMSP}_{\mathrm{d}}$ may thus be a function of extracellular release of $\mathrm{DMSP}_{\mathrm{d}}$ and its subsequent removal. As discussed elsewhere, the collapse of the early diatom bloom in the enclosures and the associated release of organic compounds (as indicated by the accumulation of DMSP $_{d}$ ) resulted in an increase in bacterial abundance and activity, as estimated by $\mathrm{M}$. Levasseur et al. (unpubl.) using the $\left[{ }^{3} \mathrm{H}\right]$ thymidine technique. Although these authors have not directly measured $\mathrm{DMSP}_{\mathrm{d}}$ or DMS bacterial degradation rates, the enhanced bacterial activity may have been responsible for the absence of DMSP $_{d}$ and DMS peaks following the collapse of the Emiliania huxleyi blooms. In L1 and L2, DMSP concentrations decreased at rates varying between 0.2 and $1.8 \mathrm{nmol} \mathrm{l}^{-1} \mathrm{~h}^{-1}$ during the collapse of the $E$. huxleyi bloom (these estimates take into account the $10 \%$ daily dilution rate of the enclosures and the DMSP $_{d}$ concentration of the dilution water). These values represent conservative estimates of the in situ DMSP $_{d}$ degradation rates since they do not take into account the production of $\mathrm{DMSP}_{\mathrm{d}}$. However, these estimates of the $\mathrm{DMSP}_{\mathrm{d}}$ degradation rate are comparable to the in situ $\mathrm{DMSP}_{d}$ degradation rates previously determined in the eastern Pacific Ocean (0.05 to $0.75 \mathrm{nmol} \mathrm{l}^{-1} \mathrm{~h}^{-1}$; Kiene \& Bates 1990) and well below those measured in the Duplin River, Georgia, USA (ca 4 nmol $\mathrm{l}^{-1} \mathrm{~h}^{-1}$ at $10^{\circ} \mathrm{C}$; Kiene \& Service 1991), Bacterial degradation of $\mathrm{DMSP}_{d}$ may thus have been high enough in the mesocosms and in the field to completely obliterate the DMSP pulse following the collapse of the E. huxleyi blooms.

During our study, the magnitude of the Emiliania huxleyi blooms was small (maximum density of ca $12 \times 10^{6}$ cells $\mathbf{l}^{-1}$ ) as compared to those previously observed during similar studies (up to ca $250 \times$ $10^{6}$ cells $\mathrm{I}^{-1}$; Bratbak et al. 1993). Bratbak et al. (1993) have shown that viral attack may cause a rapid collapse of these blooms ( 3 to $6 \mathrm{~d}$ ). Using their data, we estimated the production rate of $\mathrm{DMSP}_{d}$ following the collapse of these huge blooms by multiplying the cell loss rates by $0.5 \mathrm{pg}$ DMSP cell ${ }^{-1}$, a conservative estimate of the DMSP quota of E. huxleyi (Keller 1989, M. Levasseur et al, unpubl.). These calculations show that the virus-induced collapse of E. huxleyi blooms by 100 to $250 \times 10^{6}$ cells $\mathrm{l}^{-1}$ could potentially generate 2 to $6 \mathrm{nmol} \mathrm{DMSP}_{\mathrm{d}} \mathrm{l}^{-1} \mathrm{~h}^{-1}$ during 4 to 6 d (data from Figs. 1a and $3 c$ in Bratbak et al. 1993). It thus appears that a rapid (few days) collapse of a large E. huxleyi bloom might inject a high quantity of $\mathrm{DMSP}_{d}$ into the water that may overcome the in situ $\mathrm{DMSP}_{\alpha}$ bacterial degradation rate. Our results suggest that it is only in these conditions that cell lysis following viral infection would represent an effi-

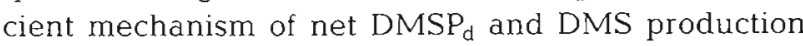
in seawater.

Acknowledgements. This work was supported by funding from the EC and from the Research Council of Norway to the MAST-II EHUX project, contract number MAS2-CT92-0038, and by a grant from the Natural Sciences and Engineering Research Council of Canada (NSERC) to M.L. E.F. acknowledges the receipt of a post-doctoral fellowship from the MEC (Spain). The electronmicroscopy work was done at the Laboratory for Electron Microscopy, University of Bergen. This is EHUX contribution number 48. 


\section{LITERATURE CITED}

Balch WM, Holligan PM, Kilpatrick AK (1992) Calcification, photosynthesis and growth of the bloom-forming coccoLithophore, Emiliania huxleyi. Cont Shelf Res 12:1353-1374

Børsheim Y, Bratbak G, Heldal H $(1990)$ Enumeration and biomass estimation of planktonic bacteria and viruses by transmission electron microscopy. Appl environ Microbiol $56: 352-66$

Bratbak G, Egge JK, Heldal H (1993) Viral mortality of the marine alga Emiliania huxleyi (Haptophyceae) and termination of algal blooms. Mar Ecol Prog Ser 93:39-48

Bratbak G, Heldal M, Norland S, Thingstad TF (1990) Viruses as partners in spring bloom microbial trophodynamics. Appl environ Microbiol 56:1400-1405

Challenger F, Simpson MI (1948) Studies on biological methylation. Part XII. A precursor of the dimethylsulfide evolved by Polysiphona fastigiata. Dimethyl-2-carboxyethylsulphonium hydroxide and its salts. J Chem Soc 3:1591-1597

Charlson RJ, Lovelock JE, Andreae MO, Warren SG (1987) Oceanic phytoplankton, atmospheric sulphur, cloud albedo and climate. Nature 326:655-661

Cottrell MT, Suttle CA (1991) Wide-spread occurrence and clonal variation in viruses which cause lysis of a cosmopolitan eucaryotic marine phytoplankter, Micromonas pusilla. Mar Ecol Prog Ser 78:1-9

Dacey JWH, Wakeham SG (1986) Oceanic dimethylsulfide: production during zooplankton grazing on phytoplankton Science 233:1314-1316

Dickson DMJ, Kirst GO (1987a) Osmotic adjustment in marine eucaryotic algae: the role of inorganic ions, quarternary ammonium, tertiary sulphonium and carbohydrate solutes - I. Diatoms and rhodophyte. New Phytol 106:647-655

Dickson DMJ, Kirst GO (1987b) Osmotic adjustment in marine eucaryotic algae: the role of inorganic ions, quarternary ammonium, tertiary sulphonium and carbohydrate solutes - II. Prasinophytes and haptophytes. New Phytol 106 $657-666$

Dymond J, Lyle $M$ (1985) Flux comparisons between sediments and sediment traps in the eastern tropical Pacific implications for atmospheric $\mathrm{CO}_{2}$ variations during the Pleistocene. Limnol Oceanogr 30:699-712

Egge JK, Aksnes DL (1992) Silicate as regulating nutrient in phytoplankton competition. Mar Ecol Prog Ser 83:281-289

Fernández E, Boyd P, Holligan PM, Harbour DS (1993) Production of organic and inorganic carbon within a largescale coccolithophore bloom in the northeast Atlantic Ocean. Mar Ecol Prog Ser 97:271-285

Holligan PM, Viollier M, Harbour DS, Camus P, ChampagnePhilippe $M$ (1983) Satellite and ship studies of coccolithophore production along a continental shelf edge. Nature 304:339-342

Johannessen PJ, Heimdal BR (1979) Hydrography and hydrochemistry from March to July 1976 in Fauskangerpollen, western Norway. Sarsia 64:171-178

Keller MD (1989) Dimethyl sulfide production and marine phytoplankton: the importance of species composition and cell size. Biol Oceanogr 6:375-382

Kiene RP (1990) Dimethyl sulfide production from dimethyl sulfoniopropionate in coastal seawater samples and bacterial cultures. Appl environ Microbiol 56:3292-3297

Kiene RP, Bates TS (1990) Biological removal of dimethyl sulphide from sea water. Nature 345:702-705
Kiene RP, Service SK (1991) Decomposition of dissolved DMSP and DMS in estuarine waters: dependence on temperature and substrate concentration. Mar Ecol Prog Ser $76: 1-11$

Leck C, Bagander LE (1988) Determination of reduced sulfur compounds in aqueous solutions using gas chromatography flame photometric detection. Analyt Chem 60 $1680-1683$

Malin G, Turner SM, Liss PS (1992) Sulfur: the plankton/ climate connection. J Phycol 28:590-597

Malin G, Turner S, Liss P, Holligan P, Harbour D (1993) Dimethylsulfide and dimethylsulphoniopropionate in the Northeast Atlantic during the summer coccolithophore bloom. Deep Sea Res 40:1487-1508

Manton I, Leadbeater BSC (1974) Fine-structural observations on six species of Chrysochromulina from wild Danish marine nanoplankton, including a description of $C$. cam. panulifera sp. nov. and a preliminary summary of the nanoplankton as a whole. Biol Skr Dan Vid Selsk 20:1-26

Matrai PA, Keller MD (1993) Dimethylsulfide in a large scale coccolithophorid bloom in the Gulf of Maine. Cont Shelf Res 13:831-843

Mayer JA, Taylor FJR (1979) A virus which lyses the marine nanoflagellate Micromonas pusilla. Nature 281:299-301

Nguyen BC, Belviso S, Mihalopoulos N, Gostan J, Nival P (1988) Dimethyl sulfide production during natural phytoplanktonic blooms. Mar Chem 24:133-141

Paasche E (1963) The adaption of the carbon-14 method for the measurement of coccolith production in Coccolithus huxleyi. Physiol Plant 16:186-200

Reisser W (1993) Viruses and virus-like particles of freshwater and marine eucaryotic algae - a review. Arch Protistenkd $143: 257-265$

Suttle CA. Chan AM, Cottrell MT (1990) Infection of phytoplankton by viruses and reduction of primary productivity. Nature 347:467-469

Suttle CA, Chan AM, Cottrell MT (1991) Use of ultrafiltration to isolate viruses from seawater which are pathogens of marine phytoplankton. Appl environ Microbiol 57:721-726

Turner SM, Malin G, Liss PS, Harbour DS, Holligan PM (1988) The seasonal variation of dimethyl sulfide and dimethylsulphoniopropionate concentrations in nearshore waters. Limnol Oceanogr 33:364-375

Utermöhl H (1931) Neue Wege in der quantitativen Erfassung des Planktons. (Mit besonderer Berücksichtigung des Ultraplanktons). Verh int Ver theor angew Limnol 5:567-596

Vairavamurthy A, Andreae MO, Iverson RL (1985) Biosynthesis of dimethylsulphide and dimethylpropiothetin by Hymenomonas carterae in relation to sulphur source and salinity variations. Linmol Oceanogr 30:59-70

van Etten JL, Lane LC, Meints RH (1991) Viruses and viruslike particles of eucaryotic algae. Microbiol Rev 55: 586-620

Waters RE, Chan AT (1982) Micromonas pusilla virus: the virus growth cycle and associated physiological events within the host cells; host range mutation. J gen Virol 63:199-206

Westbroek P (1991) Life as a geological force, dynamics of the earth. WW Norton \& Co, New York

Westbroek P, de Wrind-de Jong EW, Wal P van der, Borman A.H, Vrind JPM de (1985) Biopolymer-mediated $\mathrm{Ca}$ and $\mathrm{Mn}$ accumulation and biomineralization. Geol Mijnbouw $64: 5-15$

Manuscript first received: February 24, 1995

Revised version accepted: July 21, 1995 